\title{
CLINICOPATHOLOGICAL STUDIES ON THE EFFECT OF PEFLOXACIN ADMINISTRATION ON E. COLI INFECTED CHICKS
}

\author{
A.G. Selim \\ The Veterinary Clinic Fac. of Vet. Med., Zagazig University.
}

\begin{abstract}
This study was planed to investigate the effect of Pefloxacin on hematological and biochemical alterations in broiler chicks experimentally infected with $E$. coli. One hundred and twenty apparently healthy unsexed, one day old native broiler chicks were divided into 4 equal groups, each 30 chicks. Group (A) was kept as control group (non infected non treated). Group (B) was infected by E. coli. Group (C) infected and treated with Pefloxacin 50mg/L for three successive days. Group (D) treated only with Pefloxacin 50mg/L for three successive days.
\end{abstract}

Erythrogram data for E. coli infected groups reveled macrocytic hypochromic anemia, while infected group showed marked leukocytosis, heterophilia and monocytosis allover the experimental period. The pefloxacin treatment group showed heterophilia and monocytosis only. The activities of AST, ALT and ALP were significantly elevated with E. coli infection and Pefloxacin treated group at 14 days old. Hypoproteinemia, hypoalbunemia and hypoglobuliemia observed in infected groups. Elevated serum uric acid and creatinine have been reported in both infected groups. 


\section{INTRODUCTION}

Flouroquinolones are broad spectrum antibacterial drugs. The antibacterial action of flouroquinolones is a wide spectrum of Grampositive and Gram-negative bacteria such as E. coli and Neisseria gonorrhoea as well as Gram-positive bacteria including $S$. pneumoniae and Staphylococcus aureus (El-Sukhon and Boukhatem, 2003 and Martinez et al., 2005). Fluoroquinolones are available in human use as ciprofloxacin, norfloxacin, ofloxacin, pefloxacin and lomefloxcin (Mohan et al., 2006).

Pefloxacin is a synthetic broad spectrum fluoroquinolone antibacterial agent. It has an excellent antibacterial activity against most Gram-negative and Gram-positive bacteria. Pefloxacin is a bactericidal compound. This action results from interference with the activity of DNA gyrase and topoisomerase IV, which are needed for the transcription and replication of bacterial DNA. As a result, DNA replication and transcription are inhibited (Ibezim et al., 2006 and Moutafchieva and Yarkov, 2006).

E. coli infection in chicken (colibacillosis) is considered as one of the most serious problems responsible for economic losses to poultry industry. E. coli infection is readily recognized grossly and easily defined bacteriologically but its prevention and treatment are still more difficult (Saif et al., 2003).

The aim of the present study is to evaluate the efficacy of pefloxacin against $E$. coli infection of broiler chicks, besides studying the changes on hematological and biochemical profiles of the infected chicks after drug administration; this will be accomplished using clinicopathological means of investigations. 


\section{MATERIAL AND METHODS}

\section{Experimental chicks:}

One hundred and twenty unsexed native broiler chicks, one day old, were used in this experiment. They were obtained from $E$. coli free flock, reared under hygienic conditions and fed on basal ration free from any antimicrobial drugs, beside fresh water ad-libtum. The chicks were received all specific vaccine program, particularly for the Newcastle disease and Gamboro diseases (NRC, 1994). They were acclimatized for 7 days before the beginning of the experiment. At the $8^{\text {th }}$ day of age, the chicks were divided into four equal groups (thirty each). Group (A) was non treated and non infected chicks (control group). Group (B) was infected non-treated chicks. Group (C) was infected chicks and treated with the therapeutic dose of Pefloxacin $(5 \mathrm{mg} / \mathrm{kg}$ B.wt) for three days (Pant et al., 2005) after the onset of the clinical signs. Group (D) was non infected chicks and given the same dose of Pefloxacin ${ }^{\bullet}$ for three days (Table 1). The clinical signs and the mortality rate were recorded.

Table (1): Experimental design.

\begin{tabular}{|c|c|c|c|c|c|c|}
\hline \multirow{2}{*}{ Group } & \multirow{2}{*}{$\begin{array}{l}\text { No. of } \\
\text { chicks }\end{array}$} & \multirow{2}{*}{$\begin{array}{l}\text { Age of } \\
\text { infection }\end{array}$} & \multirow{2}{*}{$\begin{array}{l}\text { Medication/ } \\
\text { Pefloxacin }\end{array}$} & \multicolumn{3}{|c|}{$\begin{array}{c}\text { Days of sampling, sacrifice } \\
\text { and dead* }\end{array}$} \\
\hline & & & & 14 & 21 & 28 \\
\hline A & 30 & - & - & 10 & 10 & 10 \\
\hline B & 30 & 8 days & - & $5+5 *$ & $6+4^{*}$ & $7+3^{*}$ \\
\hline $\mathrm{C}$ & 30 & 8 days & $5 \mathrm{mg} / \mathrm{kg}$ B.wt & $8+2 *$ & $9+1 *$ & 10 \\
\hline $\mathrm{D}$ & 30 & - & $5 \mathrm{mg} / \mathrm{kg}$ B.wt & $9+1^{*}$ & 10 & 10 \\
\hline
\end{tabular}

*: Number of dead birds.

- Peflodad®: Manufactured by Dad Company-Jordon. It is available in the form of vials containing $100 \mathrm{ml}$. Pefloxacin is easily soluble in water. 


\section{Experimental infection:}

E. coli serotype O78 was obtained from Microbiology Department of Animal Health Research Institute, Dokki, Giza, Egypt was used for infection of the groups $\mathrm{B}$ and $\mathrm{C}$. Infection was done at the $8^{\text {th }}$ day of age with $E$. coli $\mathrm{O} 78$ strain by oral administration of $0.25 \mathrm{ml} / \mathrm{bird}\left(2 \times 10^{6}\right.$ CFU) according to Sarközy et al. (2004).

\section{Hematological and biochemical examinations:}

Two blood samples were collected from random 10 chicks of each group via wing vein puncture at 14, 21 and 28 days old. The first portion was collected in dry and clean vial containing EDTA as anticoagulant for hematological studies according to standard techniques for birds described by Feldman et al. (2000). The second portion was collected in plain centrifuge tubes and the serum was separated for measuring the activities of serum aspartate aminotransferase (AST), alanine aminotransferase (ALT) (Reitman and Frankel, 1957), and alkaline phosphatase (Kind and King, 1954). Total serum proteins (Peters, 1968), albumin (Drupt, 1974) and the serum globulins were calculated as the difference between the total proteins and albumin. The uric acid (Fossati et al., 1980) and creatinine (Seeling and Wust, 1969) were measure.

Statistical analysis:

The obtained data were statistically analyzed according to Tamhane and Dunlop (2000).

\section{RESULTES AND DISCUSSION}

\section{Clinical signs:}

Normal chicks (non infected, non treated) and also non infected and treated with pefloxacin were healthy, viable showing no clinical symptoms along the course of the experiment. Whereas E. coli infected 
broiler native chicks displayed clinical symptoms after 3 days from infection as loss of appetite, depression ruffled feathers, debility, dropped head, and diarrhoea, respiratory symptoms including sneezing, gasping, mild conjunctivitis with frothy exudates in their eyes. The same observations were recorded by El-Boraay and Abo-Taleb (2002), Saif et al., (2003), Kamel (2004) and Ibrahim (2005); moreover treatment of $E$. coli infected chicks with pefloxacin reduced the clinical symptoms and improved the health status of the infected chicks.

The changes in the erythrogram and leukogram of the present experiment were shown in Table (2), which illustrated macrocytic hypochromic anemia beside leukocytosis resulting from heterophilia and monocytosis in groups $\mathrm{B}$ and $\mathrm{C}$, while there was no changes in group $\mathrm{D}$ compared with the control group (A). However, treatment of E. coli infected birds with pefloxacin alleviate the pathologic changes in hemogram especially at 21 and 28 days old and reverting the values of erythrogram and leukogram to its nearly normal conditions. Our results coincides with Niyogi and Bhowmik (2003) and Amer et al. (2005) who reported a significant decrease in RBCs count, hemoglobin concentration and PCV of infected with E. coli non treated chickens. Whereas, treatment of infected birds with pefloxacin elevated significantly these parameters reverting them to nearly their normal values. Our data clearly reinforced by those obtained previously by Magdy and Gehad (1997) who concluded that intramuscular administration of danofloxacin to rats induced a highly significant decrease in haemoglobin contents. A significant decrease in total RBCs count, hemoglobin concentration and PCV in E. coli infected chickens have been reported by another fluoroquinolone and ofloxacin (Amer et al., 2005).

The enzymatic activities of serum AST, ALT and ALP in infected non treated group, infected treated group and treated non infected group were significantly elevated as compared with non treated non infected group (Table 3). 
Similar results for $E$. coli infection were recorded by Niyogi and Bhowmik (2003), Kamel (2004) and Ibrahim (2005) they found that infection with $E$. coli elevated significantly the serum levels of AST, ALT and ALP. On the other hand, Abd El-Latif, (1990) reported the same elevation only on AST whereas ALT was not significantly affected. They attributed the increase in enzyme activities to liver damage by the effect of the infectious agent toxins which is followed by the escape of these enzymes into serum in abnormal high levels. In addition, Ramadan (1996), Charleston et al. (1998) and Knoll et al. (1999) reported that administration of $5 \mathrm{mg} / \mathrm{kg}$ B.wt. danofloxacin for 3 days to both non infected and experimentally infected chicken with E. coli induced a significant increase in the activities of AST, ALT and alkaline phosphatase. The present findings support the results previously recorded by Domingo (1990), Eisa (1998) and Stahlmann (2002) who noted that administration of norfloxacin to rats at therapeutic dose resulted in elevated liver enzymes. Also, Kobayashi (1985) found that there were mild and reversible elevation in serum AST and ALT related to ciprofloxacin therapy. Treatment of E. coli infected chickens with pefloxacin induce a significant decrease in serum levels of serum ALT, AST and ALP activities when compared with infected non treated group. The levels of these enzymes were reverted to nearly their normal values when compared with non infected non treated control group at the end of experiment.

Regarding the effect of the tested drug on proteinogram (Table 3) revealed that serum total proteins, albumin and globulin were significantly decreased in groups B, C and D. Pefloxacin treatment infected chicks elicited non significant increases on reverting proteinogram them to nearly their control values. These effects are ascribed to the immunosuppressive response of pefloxacin. These results are clearly reinforced by Sun et al. (2001) who suggested the immune suppressing effects of ofloxacin. Our results confirm the results reported 
by Edrees et al. (2004) who found that treatment of healthy hens with pefloxacin for 5 days induce significant decrease in total protein, albumin and globulin. The decreased serum total protein levels in the present data might be explained by the renal damage provoked by the drugs as Altman (1979) reported that hypoproteinaemia can occur with renal disease. Infected chick with $E$. coli displayed a significant decrease in total protein and albumin levels when compared with control. Hypoproteinemia met with post bacterial infection in chicks in the present study coincided with those obtained by (Kamel, 2004) who mentioned that infection of chickens with E. coli showed significant decrease in serum total protein, which might be possibly attributed to its renal loss due to renal damage.

The significant increase in uric acid and creatinine values in groups $\mathrm{B}$ and $\mathrm{C}$ (Table 3 ) may be attributed to the circulation of toxins produced by $E$. coli during passing from kidney tubules causing degenerative changes and renal dysfunction. Our results coincided with El-Nabaawy et al. (1995) who said that in broilers infected with E. coli with septicemia, there were elevation in uric acid values. Also, the results of increase serum creatinine levels in native chickens infected with $E$. coli with Faten (2006) who recorded the endotoxins of E. coli in broiler chickens leading to increase plasma creatinine concentration. However, the uric acid and creatinine were retained to their nearly normal control levels in group $\mathrm{C}$ at 21 and 28 days old.

It could be concluded that $E$. coli infection in native broiler chicks creat serious hematological changes beside deterioration of liver and kidney functions. However, pefloxacin have highly curative effect against $E$. coli infection, alleviate the clinicopathological changes and regain the normal patterns of hemogram and biochemical profile of $E$. coli infected chicks. 


\section{REFERENCES}

- Abd-El-Latif AE. (1990): Effects of some drugs in-vitro and in-vivo on colibacillosis in chickens. M.V.Sc., Thesis (Pharmacology) Fac. of Vet. Med. Zag. Univ.

- Altman RB. (1979): Avian Clinical Pathology, Radiology and Infectious Disease. Pro. Of the American Animal Hospital Association, South Bend.

- Amer MS., Shihata IM., Salem HA. and Amira SA. (2005): Some pharmacological studies on ofloxacin in chickens with reference to its effect on the blood and tissues. $4 \mathrm{t}^{\mathrm{h}}$ Int. 9Sci. Conf., Mansoura, 989-1004.

- Charleston B., Gate JJ., Aitken IA., Stephan B. and Froyman R. (1998): Comparison of the efficacies of three fluoroquinolone antimicrobial agents, given as continuous or pulsed-water medication, against Escherichia coli infection in chickens. Antimicrob Agents Chemother., 42 (1):83-87.

- Domingo P. (1990): Norfioxacin induced hepatotoxicity. J. Hepatol., 11 (2): 277-278.

- Drupt F. (1974): Colorimetric method for determination of albumin. Pharm. Bio., 9: 777.

- Edrees NE., Gad GN. and Nouh WG. (2004): Efficacy and side effects of pefloxacin in laying hens. Alex. Vet. Med. J., 21 (1): 366.381 .

- Eisa AM. (1998): Clinicopathological studies on some antidiarrhoeal drugs in rabbits. M.V.Sc. Thesis, Faculty of Vet. Med. Zagazig University. 
- El-Boraay IM. and Abo-Taleb AM. (2002): Natural and experimental infection with $\mathrm{E}$. coli and/or Clostridium perfrengens type $\mathrm{A}$ in broiler type chickens. Zag. Vet. J., 30 (1): 52-64.

- El-Nabaawy M., Abdallah Y.A., Nawar A., Farid A. and Selim S.A. (1995): The role of lymphocytes adhesive molecules and cytokines in activation of chickens monocytes. Vet. Med. J., Giza, 43 (3): 313-319.

- El-Sukhon SN.and Boukhatem FZ.(2003): Activity of combinations of ceftazidime, imipenem and pefloxacin against Staphylococcus aureus, Escherichia coli and Pseudomonas aeruginosa. Int. J. Antimicrob. Agents, 22 (6):613-617.

- Faten A. (2006): Clinicopathological studies of ciprofloxacin in broilers. M.V.Sc., Thesis (Clinical Pathology), Mansoura University.

- Feldman BF., Zinkl JG. and Jain NC. (2000): Schalm's Veterinary Hematology. $5^{\text {th }}$ Ed., Lippincott Williams and Wilkins. A Wolters Company. Philadelphia, Baltimore, New York, London, Buenos Aires, Hong Kong, Sydney, Tokyo.

- Fossati P., Prencipe L. and Berti G. (1980): Enzymatic determination of uric acid. Clin. Chem. 26 (2):227-231.

- Ibezim EC., Esimone CO., Nnamani P., Onyishi, IV., Brown SA. and Obodo CE. (2006): In vitro study of the interaction between some fluoroquinolones and extracts of kola nitida seed. African Journal of Biotechnology, 5 (19): 1781-1784. 
- Ibrahim DM. (2005): Effect of marbofloxacin and the probiotic (nutrilac) in chickens. M.V.Sc. Thesis (Pharmacology) Fac. of Vet. Med., Zagazig University.

- Kamel MA. (2004): Interaction between danofloxacin and insofluper-done acetate in chickens. M.V.Sc., Thesis (Pharmacology), Fac. of Vet. Med., Zagazig University.

- Kind PR. and King EG. (1954): Colorimetric method for determination of serum alkaline phosphatase activity. Enzyme, 12: 561 .

- Knoll U., Glunder G. and Kietzmann M. (1999): Comparative study of the plasma pharmacokinetics and tissue concentrations of danofloxacin and enrofloxacin in broiler chickens. J. Vet. Pharmacol. Ther., 22 (4): 239-246.

- Kobayashi H. (1985): Summary of clinical studies on ciprofloxacin efficacy and adverse reactions. Proc. of the $14^{\text {th }}$ International Congress of Chemotherapy Kyoto, Japan.

- Magdy SA. and Gehad RM. (1997): A possible deleterious effects of danofloxacin (Advocin) in rats. Alex. J. Vet. Sci., 13(5):575-580.

- Martinez M., McDermott P. and Walker R. (2005): Pharmacology of the fluoroquinolones: A perspective for the use in domestic animals. Vet. J., Sep 8; (Epub a head of print).

- Mohan J., Sastry KV., Tyagi JS., Rao GS. and Singh RV. (2006): Residues of fluoroquinolone drugs in the cloacal gland and other tissues of Japanese quail. Br. Poult. Sci., 47 (1): 8387. 
- Moutafchieval R. and D. Yarkov (2006): Pharmacokinetics of pefloxacin in birds. Trakia J. Sci., 4 (3): 28-33.

- Niyogi D. and Bhowmik MK. (2003): Toxicopathological changes of ciprofloxacin in broiler chickens. India J. Animal Sci., 73 (1): 12-15.

- NRC “National Research Council" (1994): Nutrient requirements of poultry. $9^{\text {th }}$ Ed.; National Academy of Science, Washington, D.C. USA.

- Pant S., Rao GS., Sastry KV., Tripathi HC. and Jagmohan MJ. (2005): Pharmacokinetics and tissue residues of pefloxacin and its metabolite norfloxacin in broiler chickens.Br.Poult. Sci., 46(5):615-20.

- Peters T. (1968): Colorimeteric method for determination of total serum proteins. Clin. Chem., 14: 1147.

- Ramadan A. (1996): Pharmacokinetics aspects, egg distribution and residues of enrofloxacin in layer chickens. Bull. Fac. Pharm., Cairo Univ., 34 (1): 49-53.

- Reitman S. and Frankel S. (1957): Colorimetric determination of transaminases activity. Am. J. Clin. Path., 28:56.

- Saif YM., Barnes HJ., Glissons JR., Fadly AM., McDougald LR. and Swayne DE. (2003): Disease of Poultry. $11^{\text {th }}$ Edition. Iowa State University Press, Ames, Iowa.

- Sarközy G., Semjen G. and Laczay P. (2004): Disposition of norfloxacin in broiler chickens and turkeys after different methods of oral administration, Vet. J., 168:312-316.

- Seeling HP. and Wust H. (1969): Colorimetric method for 
determina-tion of creatinine. Arztl. Lab., 15: 34.

- Stahlmann R. (2002): Clinical toxicological aspects of fluoroquino-lones. Toxicol., 127 (1-3): 269-277.

- Sun YW., Heo E., Cho YH., Bark KM., Yoon T. and Kim T. (2001): Pefloxacin and ciprofloxacin increase UVA-induced edema and immune suppression.Photodermatol Photoimmunol Pholomed., 17 (4): 172-177.

- Tamhane AC. and Dunlop DD. (2000): Statistics and Data Analysis from Elementary to Intermediate. Upper Saddle River, USA.

$$
\begin{aligned}
& \text { در اسات باثولوجيا إكلينيكية على تأثير تناول عقار البفلوكساسين فى }
\end{aligned}
$$

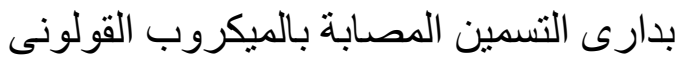

$$
\begin{aligned}
& \text { أحد جلال معوض سليم }
\end{aligned}
$$$$
\text { المستشفى البيطرى - كلية الطب البيطرى - جامعة الزقازيق }
$$

أجريت التجربة على مائة وعشرون كتكوت تسمين محلى عمر يوم, فى اليوم الثامن تم تقسيمهم إلى أربع مجموعات منساوية كل مجموعة تحتوى على 30 طائر . المجموعة الأولى تركت كمجموعة ضابطة بدون عدوى أو علاج ، المجموعة الثانية والثالثة تم إصابتهم الميكروب القولونى O:78 بعدوى معملية فى اليوم الثامن، تُركت المجموعة الثانية بدون علاج أما المجموعة الثالثة فقد نم علاجها بعد ظهور الأعـراض بثلاثـة أيسام بعقار البفلوكساسـين (5 ملجم/كجم وزن حسى) لمـدة ثنلاتـة أيسام ، أمـا المجموعة الرابعة فقد تم إعطائها عقار البفلوكساسين بنفس الجرعة لمدة ثلاثة أيام. تم تجميع عينات دم كل أسبوع بعد الانتهاء من تتاول العقار لمدة ثلاثة أسابيع. 
أظهرث النتائج عن ظهور فقر الدم فى المجموعة المصابة وغير معالجة مصحوبة بزيادة فى

عدد خلايـا الدم البيضـاء نتيجـة زيـادة عدد خلايـا النيتروفيل والوحيدات. كمـا أوضـحت الاختبـارات البيوكيميائية على مصل الطيور المصابة زيادة فى نشاط مستوى إنزيمات الكبد مع نقص معنوى فى بروتين الدم الكلى والزلال والجلوبيولين, وزيادة فى نسبة حمض البوليك والكرياتينين خلال فترة التجربة. كما أظهرت النتائج وجود زيادة فى نشاط إنزيمات الكبد مع انخفاض نسبة البروتين الكلى والزلال فى الدم بشكل مؤقت نتيجة العلاج بعقار البفلوكساسين فقط. أمسا المجموعـة الدصـابة والتى تتاولت عقـار البفلوكساسـين فقد عـادت صسورة الـدم والتحاليل البيوكيميائية الى معدلاتها الطبيعية نتيجة تتاول عقار البفلوكساسين. 